\title{
PENGARUH MODEL PEMBELAJARAN INKUIRI TERBIMBING BERBANTUAN SIMULASI PhET TERHADAP KETERAMPILAN PROSES SAINS PESERTA DIDIK SMAN 1 TANJUNG TAHUN PELAJARAN 2019/2020
}

\author{
Veza Aulia*, Hairunnisyah Sahidu, Gunawan \\ Program Studi Pendidikan Fisika, Universitas Mataram \\ *Email: vezaaulia@gmail.com
}

DOI: http://dx.doi.org/10.29303/jpft.v5i2.1543

\begin{abstract}
This research is aimed to determine the effect of guided-inquiry learning model using PhET simulation on creativity at SMAN 1 Tanjung of academic year 2019/2020. This research is quasiexperimental with non-equivalent control group design. The population of this research is all student of grade XI SMAN 1 Tanjung of academic year 2019/2020, while the sampling technique used purposive sampling, while the sampling are the student of grade XI MIPA 2 as the experimental group and the student of grade XI MIPA 1 as control group. Creativity data be measured on creativity test which the type test used 7 essay. The research hypothesis was tested using $t$-test independent. The result of $t$-test show that $t_{\text {obtained }}>t_{\text {table. }}$. It means that there is the effect of guided-inquiry learning model using PhET simulation on creativity at SMAN 1 Tanjung of academic year 2019/2020.
\end{abstract}

Keywords: guided-inquiry model, PhET simulation, creativity.

PENDAHULUAN
Fisika merupakan salah satu cabang ilmu IPA (sains) memiliki hakekat yakni fisika sebagai produk ( a body of knowledge), fisika sebagai sikap ( $a$ way of thinking) dan fisika sebagai proses (Hikmawati \& Gunada, 2013). Ilmu fisika dapat mengungkap rahasia alam dan dapat menemukan penemuan-penemuan baru berupa teknologi terapan yang bermanfaat bagi kehidupan. Fisika merupakan ilmu fundamental yang menjadi suatu tulang punggung perkembangan ilmu pengetahuan dan teknologi serta merupakan salah satu cabang ilmu pengetahuan yang sangat dekat dengan kehidupan sehari-hari (Young \& Freedman, 2001).

Perkembangan ilmu pengetahuan dan teknologi semakin pesat seiring dengan perubahan waktu. Perkembangan ilmu pengetahuan dan teknologi memberikan pengaruh yang sangat besar terhadap efektivitas dan efisiensi proses pembelajaran (Munir, 2008). Proses belajar mengajar memerlukan suatu model pembelajaran yang termasuk dalam rumpun model-model pemrosesan informasi yang menekankan bagaimana seseorang berfikir dan dampaknya terhadap cara-cara mengolah informasi (Trianto, 2010).

Berdasarkan hasil observasi dan wawancara dapat diketahui bahwa kondisi lingkungan belajar di SMAN 1 Tanjung mengalami gangguan akibat adanya bencana alam gempa bumi yang terjadi. Dampak yang paling besar pengaruhnya terletak pada kondisi psikis peserta didik yang mengalami trauma untuk belajar di sekolah khususnya untuk berada didalam ruangan kelas, akibatnya, konsentrasi dan hasil belajar peserta didik mengalami penurunan. Adapun dampak lainnya yaitu guru cenderung kesulitan dalam mengatur jam pelajaran dan menyesuaikan dengan materi pelajaran yang begitu luas sehingga terjadi keterlambatan dalam penyampaian materi yang telah direncanakan sebelumnya. Materi yang seharusnya menggunakan metode percobaan juga menjadi terhambat akibat kondisi ruangan laboratorium yang rusak sehingga keterampilan-keterampilan yang menjadi tujuan pembelajaran tidak tercapai.

Salah satu alternatif model pembelajaran yang dapat digunakan untuk 
menanggulangi permasalahan diatas dengan menerapkan model pembelajaran inkuiri terbimbing. Model pembelajaran inkuiri terbimbing ini lebih menekankan pada proses penemuan dari sebuah konsep dan juga dapat memberikan ruang untuk belajar sesuai dengan gaya peserta didik. Model pembelajaran inkuiri terbimbing memiliki prinsip keterbukaan yang berarti dalam proses pembelajaran akan selalu membuka ruang bagi peserta didik untuk mencoba sesuai tingkat perkembangan pemiliknya sehingga kreativitas yang dimiliki anak akan berkembang dalam suasana keterbukaan.

Model pembelajaran inkuiri terbimbing ini berbeda dengan model pembelajaran inkuiri. Perbedaannya model pembelajaran inkuiri lebih menekankan pada keaktifan peserta didik dalam menemukan atau mencari sendiri jawaban dari suatu permasalahan, sedangkan model pembelajaran inkuiri terbimbing guru membimbing peserta didik dengan memberikan petunjuk awal dalam menemukan atau mencari jawaban dari suatu permasalahan. Tujuan umum dari model pembelajaran inkuiri terbimbing adalah membantu peserta didik mengembangkan keterampilan intelektual dan keterampilan keterampilan lainnya, seperti mengajukan pertanyaan dan menemukan (mencari) jawaban yang berasal dari keingintahuan mereka (Tangkas, 2012). Model pembelajaran inkuiri terbimbing digunakan sebagai aternatif model pembelajaran disebabkan karena peserta didik yang tidak terbiasa dalam melakukan suatu percobaan khususnya percobaan dengan menggunakan simulasi PhET. Simulasi PhET digunakan sebagai percobaan dalam penelitian ini disebabkan karena kondisi laboratorium fisika di SMAN 1 Tanjung mengalami kerusakan akibat gempa bumi, dan juga karena kondisi ruang komputer dalam keadaan layak untuk dioperasikan sehingga simulasi PhET dapat digunakan.
Berdasarkan hasil penelitian terdahulu Deta et al. (2013) dan Yulianci et al. (2017) terdapat interaksi antara metode pembelajaran inkuiri terbimbing dengan kreativitas peserta didik terhadap prestasi belajar afektif, sedangkan untuk prestasi belajar kognitif dan psikomotor tidak terdapat interaksi. Begitu pula hasil penelitian Hayati et al. (2017) dan Wahyuni et al. (2018) menyatakan bahwa model pembelajaran inkuiri dengan menggunakan media simulasi yang diberikan pada kelas ekperimen membuat siswa lebih aktif dalam belajar dan meningkatkan hasil belajar fisika siswa. Hasil penelitian Setiadi dan Muflika (2012) menyatakan bahwa program simulasi PhET sebagai paket dari aplikasi lab virtual dapat diaplikasikan dalam pembelajaran pengembangan keterampilan proses sains, dan keterampilan yang bisa dikembangkan dari simulasi PhET ini yaitu mengamati, menafsirkan, meramalkan, dan mengkomunikasikan. Kusdiastuti et al. (2016) menyatakan bahwa model pembelajaran inkuiri berbantuan media berbasis komputer mampu meningkatkan penguasaan konsep peserta didik. Dari beberapa hal yang sudah dikemukakan mendorong peneliti untuk melakukan penelitian menggunakan model pembelajaran inkuiri terbimbing berbantuan simulasi PhET untuk meningkatkan keterampilan proses peserta didik.

\section{METODE PENELITIAN}

Jenis penelitian yang digunakan dalam penelitian ini adalah eksperimen semu (Kuasi Eksperimen) dengan rancangan penelitian yaitu untreated control group design with pretest-posttest juga sering disebut dengan nonequivalent control group design. Kelas eksperimen diberikan perlakuan dengan menggunakan model inkuiri terbimbing berbantuan simulasi PhET. Sedangkan pada kelas kontrol diberikan perlakuan dengan menggunakan 
model pembelajaran konvensional. Instrumen yang digunakan yaitu tes uraian berisi 7 soal dengan subyek penelitian ini adalah siswa kelas XI di SMAN 1 Tanjung Tahun Pelajaran 2019/2020. Kelas XI MIA 2 dipilih sebagai kelas eksperimen dan kelas XI MIA 1 sebagai kelas kontrol dengan teknik sampling purposive.

Data hasil kreativitas di uji prasyarat analisis berupa uji homogenitas menggunakan uji-F dan uji normalitas menggunakan uji Chi Kuadrat. Uji hipotesis menunggunakan uji t independen.

\section{HASIL DAN PEMBAHASAN}

Penelitian ini bertujuan untuk menguji pengaruh model pembelajaran inkuiri terbimbing berbantuan simulasi PhET terhadap keterampilan proses sains peserta didik SMAN 1 Tanjung tahun pelajaran 2019/2020.

Indikator kreativitas yang diukur ada empat, diantaranya kreativitas figural, kreativitas verbal, kreativitas numerik, dan kreativitas prosedural. Indikator kreativitas ini diukur menggunakan tes uraian pada tes awal dan tes akhir yang terdiri dari 7 soal. Tes awal (pretest) diberikan pada awal pembelajaran sebelum diberikan perlakuan digunakan untuk mengetahui kemampuan awal peserta didik tentang materi fluida dinamis. Hasil tes awal dari kelas eksperimen dan kelas kontrol dapat dilihat pada Tabel 1.

Tabel 1. Hasil Tes Awal Kreativitas

\begin{tabular}{ccccc}
\hline Kelas & $\mathbf{N}$ & Nilai Terendah & Nilai Tertinggi & Rata-rata \\
\hline Eksperimen & 26 & 9,5 & 61,9 & 48,2 \\
Kontrol & 25 & 19,0 & 57,1 & 40,1 \\
\hline
\end{tabular}

Pada Tabel 1, terlihat bahwa nilai tertinggi untuk kelas eksperimen adalah 61,9, sedangkan nilai tertinggi untuk kelas kontrol adalah 57,1. Nilai terendah pada kelas eksperimen adalah 9,5 dan pada kelas kontrol adalah 19,0. Rata-rata nilai tes awal kelas eksperimen dan kelas kontrol masih dalam kategori rendah. Secara grafik nilai tes awal kreativitas ditunjukkan pada gambar 4.1

Tes akhir (posttest) diberikan pada akhir pembelajaran setelah diberikan perlakuan untuk mengetahui apakah terjadi peningkatan kreativitas peserta didik dalam proses pembelajaran.Adapun hasil tes akhir dapat dilihat pada Tabel 2 .

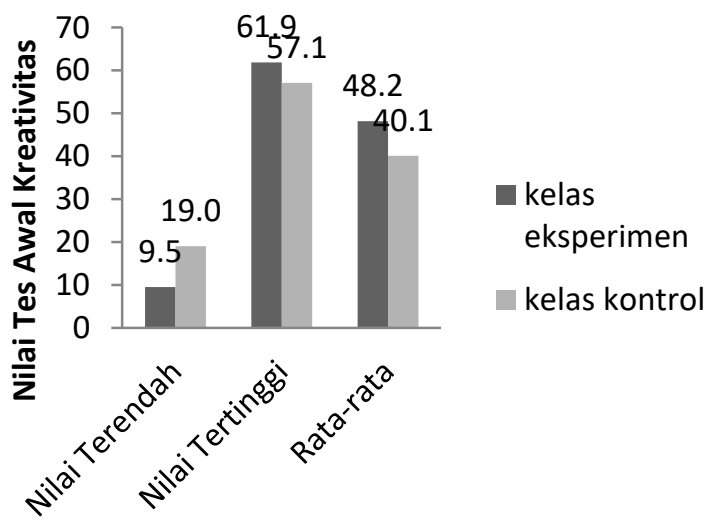

Gambar 1. Nilai Tes Awal Kreativitas

Tabel 2. Hasil Tes Akhir Kreativitas

\begin{tabular}{llccc}
\hline \multicolumn{1}{c}{ Kelas } & N & Nilai Terendah & Nilai Tertinggi & Rata-rata \\
\hline Eksperimen & 26 & 61,9 & 100,0 & 85,2 \\
Kontrol & 25 & 61,9 & 95,2 & 74,4 \\
\hline
\end{tabular}

Tabel 2 menunjukkan bahwa nilai tertinggi pada kelas eksperimen adalah 100,0 dan kelas kontrol adalah 95,2 .Sedangkan nilai terendah pada kelas eksperimen dan kelas kontrol bernilai sama yaitu 61,9. Rata-rata nilai kelas eksperimen dan kelas kontrol yaitu sebesar 85,2 dan 74,4. Data pada Tabel 2 menunjukan bahwa hasil tes akhir pada kelas eksperimen dan kelas kontrol mengalami peningkatan 
dibandingkan dengan nilai tes awal dari segi nilai tertinggi, nilai terendah, dan nilai ratarata. Secara grafik nilai tes akhir kreativitas ditunjukkan pada Gambar 1.

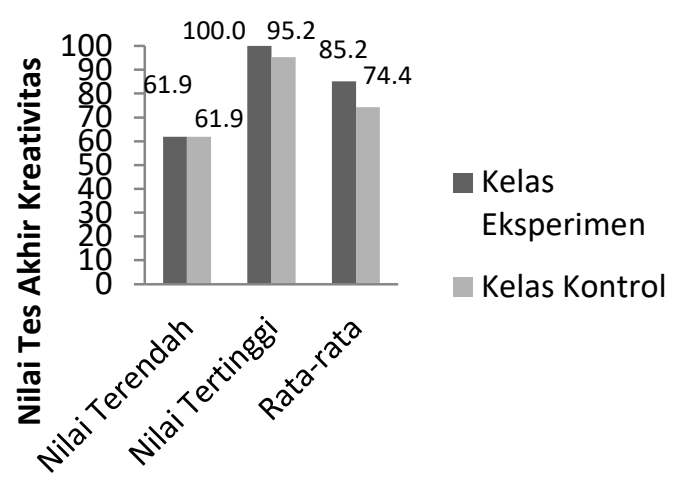

Gambar 1. Nilai Tes Akhir Kreativitas

Hasil uji prasyarat sebelum melakukan uji hipotesis pada penelitian ini berkaitan dengan uji homogenitas dan uji normalitas pada hasil tes awal dan tes akhir. Uji homogenitas dianalisis dengan menggunakan uji $F$ dan hasilnya menunjukkan bahwa nilai tes awal dari kelas eksperimen dan kelas kontrol memiliki kemampuan awal yang sama atau homogen. Hasil uji normalitas untuk tes awal kedua kelas diperoleh nilai yang terdistribusi normal dengan $\chi_{\text {hit }}^{2}<\chi_{\text {tab }}^{2}$. Secara kasat mata, data dapat dikatakan terdistribusi normal karena penyebaran nilai untuk kelas eksperimen maupun kelas kontrol tersebar secara merata baik untuk nilai tertinggi maupun nilai terendah. Pengujian normalitas data dilakukan untuk mengetahui normal tidaknya suatu distribusi data untuk menentukan ketepatan pemilihan uji statistik yang digunakan sehingga pengujian normalitas harus dilakukan jika belum ada teori yang menyatakan bahwa variabel yang diteliti adalah normal (Rahayu, 2014).

Tes awal dan tes akhir yang berisi pertanyaan digunakan untuk mengukur kreativitas peserta didik. Hasil tes awal menunjukkan bahwa, pada kelas eksperimen maupun kelas kontrol memiliki kreativitas yang rendah. Hal tersebut ditunjukkan pada jawaban dari tes awal tersebut masih terpaku pada suatu hal yang mendasar yang diketahui oleh peserta didik mengenai materi fluida dinamis. Penyebab rendahnya kreativitas fisika peserta didik juga disebabkan karena kedua kelas belum mempelajari materi fluida dinamis dan juga belum diberikan perlakuan. Peningkatan kreativitas terjadi setelah peserta didik diberikan perlakuan, baik pada kelas eksperimen ataupun kontrol. Hasil penelitian Nulaila et al. (2013), menyimpulkan bahwa prestasi belajar peserta didik yang memiliki kreativitas tinggi lebih baik dari peserta didik yang memiliki kreativitas rendah karena peserta didik dengan kreativitas tinggi memiliki ciri-ciri antara lain: a) kelancaran berfikir (fluency of thinking) yang menggambarkan banyaknya gagasan yang keluar dalam pemikiran seseorang; b) fleksibilitas (keluwesan) yaitu kemampuan untuk menggunakan bermacam-macam pendekatan dalam mengatasi persoalan; c) orisinalitas (keaslian) yaitu kemampuan seseorang untuk mencetuskan gagasan asli; d) elaborasi yaitu kemampuan unruk mengembangkan ide-ide tersebut secara terperinci, karena siswa yang memiliki kreativitas tinggi memiliki banyak gagasan dan mampu mengembangkan ide-ide dalam mengatasi persoalan baru, sehingga lebih mudah mengerjakan soal yang bersifat penerapan.

Pembelajaran menggunakan model pembelajaran inkuiri terbimbing berbantuan simulasi PhET dapat meningkatkan kreativitas fisika peserta didik. Fase pertama menuntut peserta didik untuk mengembangkan kreativitas dalam berpikir ketika diberikan suatu permasalahan dan membuat hipotesis dari suatu permasalahan tersebut pada fase kedua sehingga aspek verbal dalam kreativitas akan muncul. Fase ketiga yaitu peserta didik dituntun untuk merancang percobaan dengan menggunakan simulasi PhET dan melakukan percobaan 
untuk memperoleh informasi pada fase keempat sehingga akan muncul aspek prosedural dan aspek figural dalam kreativitas. Simulasi PhET digunakan untuk meningkatkan kreativitas fisika peserta didik karena dalam simulasi PhET peserta didik dituntut untuk merangkai berberapa model bentuk simulasi dengan kreatif . Fase kelima yaitu peserta didik mengumpulkan dan menganalisis data yang diperoleh dalam percobaan sehingga akan muncul aspek numerik serta aspek figural pada kreativitas. Fase terakhir yaitu peserta didik membuat kesimpulan berdasarkan percobaan dan pembelajaran yang telah dilakukan sehingga akan muncul aspek verbal pada kreativitas didalamnya.

Berdasarkan data tes akhir yang didapatkan diketahui aspek kreativitas yang memiliki nilai paling tinggi dan paling

rendah. Aspek yang paling tinggi nilainya untuk kelas eksperimen adalah aspek verbal, sedangkan untuk kelas kontrol adalah aspek figural. Aspek yang paling rendah nilainya untuk kelas eksperimen adalah aspek figural sedangkan untuk kelas kontrol adalah aspek numerik. Peningkatan yang paling tinggi untuk kelas eksperimen yaitu pada aspek numerik, sedangkan peningkatan paling rendah nya yaitu aspek prosedural. Peningkatan yang paling tinggi untuk kelas kontrol terdapat pada aspek figural, sedangkan yang paling rendah terdapat pada aspek numerik, untuk lebih jelasnya peningkatan tiap aspek dari kreativitas untuk kelas eksperimen dapat dilihat dari Gambar 2 .

Sedangkan peningkatan tiap aspek kreativitas untuk kelas kontrol dapat dilihat dari Gambar 3.

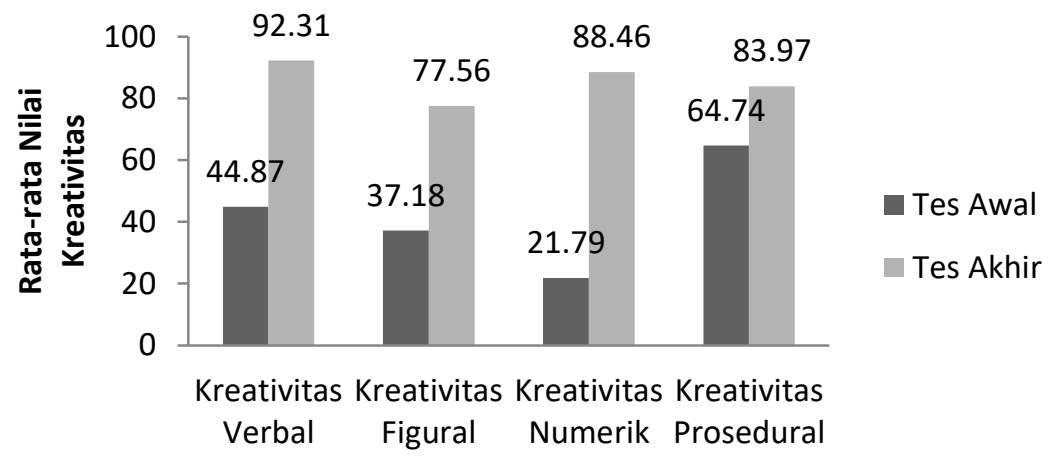

Gambar 2. Nilai Kreativitas Tiap Aspek Kelas Eksperimen

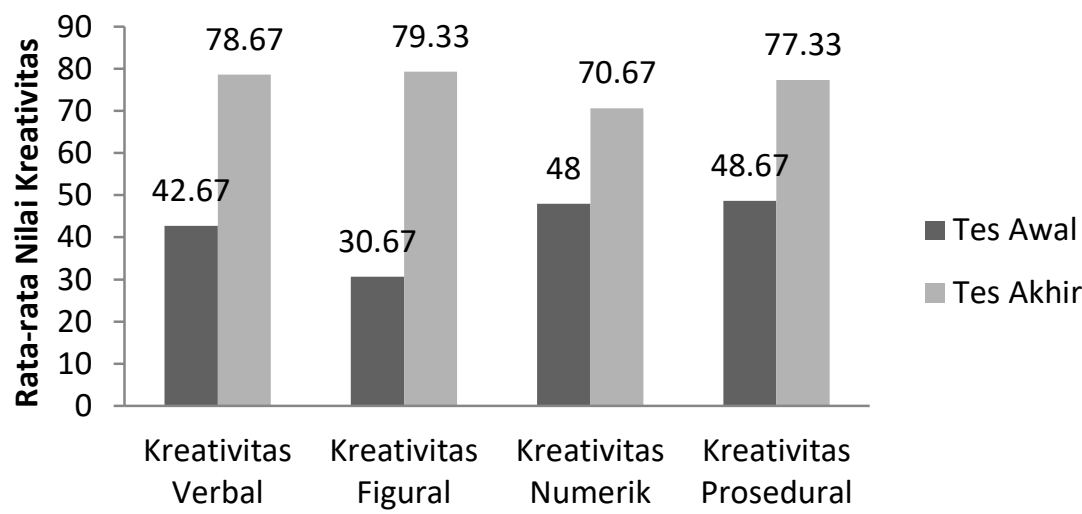

Gambar 3. Nilai Kreativitas Tiap Aspek Kelas Kontrol

\section{PENUTUP}

Berdasarkan uji hipotesis, dapat disimpulkan bahwa terdapat pengaruh kreativitas fisika peserta didik pada kelas eksperimen yang diberikan perlakuan berupa penggunaan model pembelajaran inkuiri terbimbing berbantuan simulasi $\mathrm{PhET}$. Adapun saran yang dapat diberikan 
untuk peneliti selanjutnya yaitu diperlukan pemberian pra pembelajaran agar peserta didik tidak mengalami kesulitan dalam memahami pembelajaran dengan menggunakan media simulasi PhET, serta memastikan kesiapan lab komputer agar dapat digunakan dengan baik dalam pembelajaran.

\section{REFERENSI}

Deta, U.A., Suparmi, S. \& Sunarno, W. 2013. Pengaruh Metode Inkuiri Terbimbing dan Proyek, Kreativitas, serta Keterampilan Proses Sains Terhadap Prestasi Belajar Siswa. Jurnal Pendidikan Fisika Indonesia.

Hayati, S.N., Hikmawati., Wahyudi. 2017. Pengaruh Model Pembelajaran Inkuiri Dengan Menggunakan Media Simulasi Terhadap Hasil Belajar Fisika Siswa Kelas X MIA SMAN 1 Lingsar Lombok Barat Tahun 2016/2017. Jurnal Pendidikan Fisika dan Teknologi (ISSN. 2407-6902) Volume 3(1).

Hikmawati, \& Gunada, I.W. 2013. Kajian fisika SMA. Mataram: FKIP Uniersitas Mataram.

Kusdiastuti, M., Harjono A., Sahidu H., \& Gunawan G.. (2017). Pengaruh Model Pembelajaran Inkuiri Berbantuan Laboratorium Virtual Terhadap Penguasaan Konsep Fisika Peserta Didik. Jurnal Pendidikan Fisika dan Teknologi, 2(3), 116-122.

Munir. 2008. Kurikulum Berbasis Teknologi Informasi dan Komunikasi. Bandung: Alfabeta.

Nurlaila, N., Suparmi, S., \& Sunarno, W. 2013. Pembelajaran Fisika dengan $P B L \quad$ Menggunakan Problem Solving dan Problem Posing Ditinjau dari Kreativitas dan Keterampilan Berpikir Kritis Siswa. Jurnal Inkuiri 2(2).
Rahayu, S. 2014. Diktat Statistik Dasar Untuk Pendidikan Fisika Semester 3. Mataram: Tidak diterbitkan.

Setiadi, R., \& Muflika, A. A. 2012. Eksplorasi Pemberdayaan Courseware Simulasi PhET Untuk Membangun Keterampilan Proses Sains Siswa SMA. Jurnal Pengajaran MIPA UPI 17(2).

Tangkas, I. M. 2012. Pengaruh Implementasi Model Pembelajaran Inkuiri Terbimbing Terhadap Kemampuan Pemahaman Konsep dan Keterampilan Proses Sains Peserta Didik Kelas X SMAN 3 Amplura. Jurnal Penelitian Pascasarjana Uniksha.

Trianto. 2010. Mendesain Model Pembelajaran Inovatif Progresif Konsep, Landasan dan Implementasinya pada Kurikulum Tingkat Satuan Pendidikan (KTSP). Jakarta: kencana Prenada Media Group.

Wahyuni, S., Kosim, \& Gunawan. 2017. Pengembangan Perangkat Pembelajaran Fisika Berbasis Inkuiri Terbimbing Berbantuan Eksperimen Untuk Meningkatkan Penguasaan Konsep Siswa. Jurnal Pendidikan Fisika dan Teknologi, 4(2), 240-246.

Young, H., \& Freedman, R. 2001. Fisika Universitas Jilid 2 Edisi Kesepuluh. Jakarta: Erlangga.

Yulianci, S., Gunawan, \& Doyan, A. 2017. Model Inkuiri Terbimbing Berbantuan Multimedia Interaktif Untuk Meningkatkan Penguasaan Konsep Fisika Peserta Didik. Jurnal Pendidikan Fisika dan Teknologi, 3(2), 146-154. 